\title{
PARTICIPANT PERCEPTIONS AND DECISION-MAKING CONCERNING RETIREMENT BENEFITS
}

\author{
Colleen E. Medill* \\ CRR WP 2008-9 \\ Released: February 2008 \\ Draft Submitted: January 2008 \\ Center for Retirement Research at Boston College \\ Hovey House \\ 140 Commonwealth Avenue \\ Chestnut Hill, MA 02467 \\ Tel: 617-552-1762 Fax: 617-552-0191 \\ http://www.bc.edu/crr
}

* Colleen E. Medill is a professor at the University of Nebraska College of Law. The research reported herein was performed pursuant to a grant from the U.S. Social Security Administration (SSA) funded as part of the Retirement Research Consortium. The opinions and conclusions expressed are solely those of the author and should not be construed as representing the opinions or policy of SSA, any agency of the Federal Government, the University of Nebraska, or Boston College. Additional funding for this project was provided by the University of Nebraska-Lincoln College of Law.

(C) 2008, by Colleen E. Medill. All rights reserved. Short sections of text, not to exceed two paragraphs, may be quoted without explicit permission provided that full credit, including $(\odot$ notice, is given to the source. 


\title{
About the Center for Retirement Research
}

The Center for Retirement Research at Boston College, part of a consortium that includes parallel centers at the University of Michigan and the National Bureau of Economic Research, was established in 1998 through a grant from the Social Security Administration. The Center's mission is to produce first-class research and forge a strong link between the academic community and decision makers in the public and private sectors around an issue of critical importance to the nation's future. To achieve this mission, the Center sponsors a wide variety of research projects, transmits new findings to a broad audience, trains new scholars, and broadens access to valuable data sources.

\author{
Center for Retirement Research at Boston College \\ Hovey House \\ 140 Commonwealth Avenue \\ Chestnut Hill, MA 02467 \\ phone: 617-552-1762 fax: 617-552-0191 \\ e-mail: crr@bc.edu \\ www.bc.edu/crr
}

\author{
Affiliated Institutions: \\ American Enterprise Institute \\ The Brookings Institution \\ Center for Strategic and International Studies \\ Massachusetts Institute of Technology \\ Syracuse University \\ Urban Institute
}




\begin{abstract}
From 1964 until 2002, the State of Nebraska sponsored a defined contribution plan for its employees. During this period, the plan was unique among state pension plans because it was an individual account-type plan that offered participants the choice of a lump sum or annuity distribution upon retirement. Such a choice presents the opportunity to learn more about how individuals perceive financial risks and weigh various factors when deciding how to access their retirement benefits. This study reports the results of a new survey of Nebraska state workers who retired or terminated employment in 1997. The results offer a perspective on how individuals perceive their decisions 10 years later. The findings reveal three general themes. First, retirees tended to underestimate the financial risks associated with uninsured health care expenses. Sixty-five percent of retiree respondents said that they had initially underestimated such risk. Second, federal policies may influence the distribution decision. For example, many respondents cited tax penalties on lump sum distributions as a major factor in their decision, which is consistent with a high percentage choosing a non-taxable direct rollover distribution. Finally, the results provide a basis for cautious optimism that retirees will be able to successfully manage a present value sum distribution during retirement. Over 90 percent of retiree respondents reported that they were able to cover their living expenses 10 years after their retirement.
\end{abstract}




\section{Introduction}

From 1964 until 2002, the State of Nebraska sponsored a defined contribution plan (the "State Employees Plan") for employees of state government. ${ }^{1}$ During this period, the State Employees Plan was unique among state government-sponsored public pension plans because it was an individual account-type plan that offered participants the choice of a present value sum ${ }^{1}$ or an annuity form of distribution for their vested account balances.

Such a choice presents the opportunity to learn more about how individuals perceive various types of financial risks and weigh various motivational factors when deciding whether to choose a present value sum or an annuity for the distribution of their retirement benefits (the "distribution decision"). This study focused on participants in the State Employees Plan who either retired or terminated employment in 1997 and who were eligible at that time to receive a distribution of their retirement benefits (collectively, the "1997 Population"). The study was conducted as a mail survey to collect individual-level data concerning how members of the 1997 Population assessed longevity, inflation, investment and health shock risks and the factors that motivated their distribution decisions in 1997. The survey further collected individual-level demographic data, including data on financial literacy and efforts at retirement planning, and data concerning the investment and consumption experiences of the members of the 1997 Population for the ten-year period following the distribution decision.

\footnotetext{
${ }^{1}$ The State Employees Plan covers all permanent employees of the State of Nebraska who have completed twelve consecutive months of service except: (1) state judges; (2) state patrol officers; (3) Nebraska Department of Education employees who participate in the state's School Employees Retirement Plan; (4) employees of the University of Nebraska, state colleges, and community colleges; and (5) other miscellaneous categories of workers. These state employees also are eligible to make additional voluntary contributions on a pre-tax basis to another defined contribution plan sponsored under Section 457 of the Internal Revenue Code.

The State Employees Plan was converted to a cash balance (defined benefit) plan on April 18, 2002. Participants in the State Employees Plan today continue to have the option of choosing between a present value sum or an annuity form of distribution of vested benefits.

${ }^{1}$ As used in this paper, the term "present value sum" refers collectively to taxable lump sum distributions and nontaxable direct rollover distributions. When the data is analyzed using these subcategories, the terms "lump sum" and "direct rollover" are used to distinguish between the two types of distributions of a present
} 


\section{Background}

A substantial body of scholarly literature addresses how a rational actor would perceive and make optimal decisions concerning longevity, inflation, investment and health shock risks in managing retirement wealth. A critical decision point occurs when the individual must decide whether to elect a distribution of retirement benefits in the form of a present value sum or an annuity. For individuals who elect to receive a present value sum, there is an ongoing series of decisions concerning the investment and consumption of retirement assets. Factors suggested by the literature as possibly influencing the distribution decision include: other sources of retirement income (e.g., Social Security benefits and personal savings); competing desires for immediate consumption of retirement wealth and inter-generational wealth transfer; overestimates of future rates of investment return; underestimates of longevity, inflation, stock market volatility and health shock risks; and the undervaluing of annuities (Scott, Watson and $\mathrm{Hu}$ 2007; Hu and Scott 2007; Horneff et al. 2006; Coile and Milligan 2006; Rohwedder and Van Soest 2006; Van Soest and Kapetyn 2006; Munnell and Sundén 2004; Dus, Maurer and Mitchell 2004).

Using aggregate-level data, researchers have studied the transition from the retirement asset accumulation phase of the life cycle during an individual's working years to the consumption phase beginning with the early retirement years. The results of these studies are mixed. Some retirees appear to maintain their pre-retirement wealth and consumption levels while others experience a sharp decline in wealth and consumption levels shortly after retirement begins (Copeland 2007; Hurd and Rohwedder 2006; Haveman et al. 2005). Researchers studying this sharp decline in consumption immediately following retirement - a phenomenon known as the retirement-consumption puzzle - have suggested multiple theories to explain both the retirement-consumption puzzle and the divergent outcomes produced by aggregate-level data research (Hurd and Rohwedder 2006). Although Hurd and Rehwedder found that some individuals may be reducing consumption in retirement by substituting increased leisure time for goods that are complements to leisure, they conclude that no single explanation can account for the 
decline in consumption at retirement. One partial explanation is that some individuals may have unknowingly or knowingly undersaved for retirement, but did not reduce consumption until forced to do so because of a decline in income upon entering retirement. This explanation is consistent with numerous research studies finding that between 20 and 50 percent of the population reaches retirement with insufficient financial resources (Rohwedder 2006). Another partial explanation is that some individuals experienced unexpected health problems that either forced an earlier than planned retirement, or experienced unanticipated high health care expenses in retirement (Rohwedder 2006).

These partial explanations suggest that a non-trivial percentage of individuals may suffer from sub-optimal planning for retirement. Research focusing on financial literacy, retirement planning, and retirement wealth has found that retirement planners, who tend to have higher levels of financial literacy, accumulate more retirement wealth (Lusardi and Mitchell 2006a; Lusardi and Mitchell 2006b). One variable common to both financial literacy and retirement planning is the accuracy with which individuals perceive various types of retirement financial risks. Another key variable in retirement planning is the individual's motivations for saving and planning. These motivations may be complementary to, or compete with, a desire for personal and/or spousal financial security during retirement.

Risk perceptions and motivations also play a potential role in understanding another retirement "puzzle" - why individuals undervalue annuities (Hu and Scott 2007; Horneff et al. 2006). For most workers who participate in a defined contribution plan, the only distribution option is a present value sum. Although in theory an individual voluntarily could use these funds to purchase an annuity, in practice very few individuals do so (Hu and Scott 2007; Davidoff et al. 2005; Dushi and Webb 2004; Brown et al. 2001). Research finding that retirees with less annuitized wealth consume more in the early retirement years than retirees with more annuitized retirement wealth raises the policy concern that future retirees (whose retirement benefits are increasingly likely to come solely from a defined contribution plan) may be at a higher risk of overconsuming and depleting their retirement plan assets before they die (Butrica and Mermin 2006). 


\section{Survey Methodology}

The 1997 Population provided a unique opportunity to collect individual-level data on the risk perceptions and motivations that underlie the distribution decision. The researcher designed the mail survey as a twelve-page booklet consisting of six main topical sections with a total of 35 questions. The section topics, questions and answers are described in conjunction with the data results presented below. In tabulating the data, survey respondents were coded as either "workers" (age 61 or younger) or "retirees" (age 62 or older) at the time of the distribution decision in 1997. Distribution decisions were coded as either an annuity, a present value sum (further subcoded as either a taxable "lump sum" or a nontaxable "direct rollover"), or as "no distribution" for individuals who elected to keep their account balance invested with the State Employees Plan and did not take a distribution in 1997. Survey respondents also could indicate "other" for their form of distribution and give an open-ended explanation. All of the "other" responses were successfully recoded into one of the above categories based on the open-ended explanation.

The format of the survey instrument was designed by the Bureau of Sociological Research at the University of Nebraska-Lincoln ("BOSR”) for use with computer software to electronically scan survey responses. The BOSR also provided the researcher with technical assistance in the wording of the survey questions and answers. Because Nebraska state confidentiality laws prohibited the disclosure of home address information directly to the researcher, the administrator for the State Employees Plan, the Nebraska Public Employees Retirement System ("NPERS"), provided the home address information of record as of 1997 for the 1997 Population directly to the Nebraska State Government Print Shop. The Print Shop then printed and mailed the surveys to the 1997 Population using the 1997 home address information. Surveys with outdated home addresses were returned by the U.S. Postal Service directly to the BOSR. The BOSR researched current home address information using the outdated address on the returned survey envelope and, when possible, remailed the survey materials to a current home address.

To the extent possible within the legal and budgetary constraints presented by the 
project, the researcher used The Tailored Design Method of survey methodology to maximize the survey response rate (Dillman 2007). To pretest the survey instrument, the NPERS provided the researcher with the most current home telephone number of record as of 1997 for 50 individuals from the 1997 Population (the "Cognitive Interview List"). The researcher telephoned and conducted cognitive oral interviews with four individuals selected at random from the Cognitive Interview List using the draft survey instrument. Based on feedback from these cognitive telephone interviews, the researcher revised the survey instrument. The researcher next telephoned and received permission from six different randomly selected individuals from the Cognitive Interview List to mail the revised written test survey instrument to them. The researcher requested that each of these six individuals complete and return the revised written test survey instrument to the BOSR within two weeks' time. Four of these six individuals completed and returned the revised written test survey instrument within the two-week period. The researcher then conducted a brief cognitive telephone interview with each of these four individuals to assess the revised written test survey instrument in terms of content, clarity, and ease of response. Based on feedback from this second round of telephone cognitive interviews, the researcher made only slight modifications to the final survey instrument that was mailed to the 1997 Population. A copy of the final survey instrument may be downloaded from the BOSR Web site at http://bosr.unl.edu/npers.html. Final survey results will be posted at this Web site at a future date.

A total of 1,564 survey packets, consisting of: (1) the final survey instrument; (2) a cover letter with an informed consent notice; (3) a postage-paid return envelope; and (4) a postage-paid reply postcard for permission to contact the individual for participation in a possible future study were mailed on June 7, 2007. As of July 17, 2007, the BOSR had received 630 survey packets that were undeliverable due to outdated home address information from the initial mailing. In addition, 16 survey packets were returned to the BOSR because the addressee was deceased. Of the 630 undeliverable surveys, address information for 210 of the surveys was researched and these survey packets were resent on July 9, 2007. As of July 17, 2007, 82 valid completed surveys had been returned and scanned by the BOSR into the database using survey-reading software. The data 
presented below represent a survey response rate of 7 percent through July $17,2007{ }^{2}$

The legal constraints requiring the NPERS to maintain the confidentiality of the names and home addresses of the 1997 Population limited the researcher's ability to utilize standard mail survey design features that may improve response rates, such as personalized follow-up contacts with nonrespondents (Dillman 2002; Moore and Tarnai 2002). Efforts to track and resend the remaining 420 undeliverable survey packets and add any subsequent completed and returned surveys to the data set are ongoing. Therefore, the data results presented below are preliminary.

The large number of remaining undeliverable surveys warrants caution in generalizing the results presented below to the experiences of the 1997 Population as a whole. In particular, the data collected to date may be biased by self-selection among the survey respondents. The preliminary data results are more likely to reflect the experiences of members of the 1997 Population who are more stable (have stayed at the same home address for the past ten years), more educated with higher cognitive abilities, and more interested in retirement financial planning issues (Knäuper et al. 1997).

\section{Preliminary Survey Results}

Table 1 compares the known characteristics of the 1997 Population with the survey respondents. Table 2 presents descriptive statistics for the survey respondents.

\footnotetext{
${ }^{2}$ The survey response rate was calculated by subtracting from the 1,564 original mailed surveys the 420 remaining undeliverable surveys, untrackable returned surveys, surveys returned because the addressee was deceased, and surveys returned by respondents who indicated that they did not meet the criteria for membership in the 1997 Population (Moore and Tarnai 2002; Armstrong and Overton 1977). This resulted in a survey response rate of 7 percent $(82 / 1117)$.
} 
Table 1: Comparison of the 1997 Population With the Survey Respondents ${ }^{3}$

\begin{tabular}{|l|c|c|}
\hline & $\begin{array}{l}\text { NPERS } \\
\text { Population } \\
\text { (1997) }\end{array}$ & $\begin{array}{l}\text { Survey } \\
\text { Responses } \\
\text { (2007) }\end{array}$ \\
\hline Total & $\mathbf{1 , 6 0 7}$ & $\mathbf{8 2}$ \\
\hline Retirees & 320 & 27 \\
\hline Column Percent & $19.91 \%$ & $32.93 \%$ \\
\hline Workers & 1,387 & 54 \\
\hline Column Percent & $86.31 \%$ & $65.85 \%$ \\
\hline [ System Missing (\%)] & -- & {$[1(1.22 \%)]$} \\
\hline Form of Distribution & & \\
\hline Annuity & 63 & 9 \\
\hline Column Percent & $3.92 \%$ & $10.98 \%$ \\
\hline Other Form & 1,544 & 70 \\
\hline Column Percent & $96.08 \%$ & $85.37 \%$ \\
\hline [ System Missing (\%)] & -- & {$[3(3.66 \%)]$} \\
\hline
\end{tabular}

\footnotetext{
${ }^{3}$ Within Table 1, data on the known characteristics of the 1997 Population was provided by the NPERS at the initial stage of the project. When the NPERS provided the mailing list to the Nebraska Government Print Shop, address information for only 1,564 individuals was contained on the final mailing list. Additionally, "System Missing" reflects responses not provided by the respondent on the question or characteristic being analyzed, while "Other Form" of distribution includes Present Value Sum or No Distribution.
} 
Table 2: Descriptive Statistics for Survey Respondents

\begin{tabular}{|c|c|c|c|}
\hline \multirow[b]{2}{*}{ Distribution Type } & \multirow[b]{2}{*}{ Total } & \multicolumn{2}{|c|}{ Respondents } \\
\hline & & RETIREES & WORKERS \\
\hline Lump Sum & $22.78 \%$ & $12.00 \%$ & $26.32 \%$ \\
\hline Direct Rollover & $62.03 \%$ & $64.00 \%$ & $57.89 \%$ \\
\hline Annuity & $11.39 \%$ & $24.00 \%$ & $5.26 \%$ \\
\hline No Distribution & $7.59 \%$ & $0.00 \%$ & $10.53 \%$ \\
\hline Valid & $79^{4}$ & $25(100 \%)$ & $57(100 \%)$ \\
\hline \multicolumn{4}{|l|}{ Gender } \\
\hline Female & $66.25 \%$ & $59.26 \%$ & $69.81 \%$ \\
\hline Male & $33.75 \%$ & $40.74 \%$ & $30.19 \%$ \\
\hline Valid & $80(100 \%)$ & $27(100 \%)$ & $53(100 \%)$ \\
\hline \multicolumn{4}{|l|}{ Education Level } \\
\hline High school or less & $15.19 \%$ & $25.93 \%$ & $9.62 \%$ \\
\hline Some college & $37.97 \%$ & $44.44 \%$ & $62.07 \%$ \\
\hline Bachelor's degree or higher & $46.84 \%$ & $29.63 \%$ & $55.77 \%$ \\
\hline Valid & $79(100 \%)$ & $27(100 \%)$ & $52(100 \%)$ \\
\hline \multicolumn{4}{|l|}{ Marital Status (1997) } \\
\hline Married & $79.75 \%$ & $77.78 \%$ & $80.77 \%$ \\
\hline Not married & $20.25 \%$ & $22.22 \%$ & $19.23 \%$ \\
\hline Valid & $79(100 \%)$ & $27(100 \%)$ & $52(100 \%)$ \\
\hline Age (1997) & Mean & & \\
\hline & 53.26 & 65.63 & 47.07 \\
\hline (Std. Deviation) & (SD 11.67) & (SD 3.35) & (SD 9.12) \\
\hline
\end{tabular}

As compared with the known characteristics of the 1997 Population, Table 1 shows that the survey respondents are disproportionately retirees and disproportionately selected the annuity distribution form. Table 2 shows that more than $80 \%$ of all survey respondents chose a present value sum and more than $60 \%$ chose a nontaxable direct rollover. Among retirees, 24\% chose an annuity.

Section One of the survey asked a series of questions that required respondents to recall their perceptions of longevity, inflation, investment and health shock risks (further subcoded as medical care expenses and long-term care expenses) in making the distribution decision in 1997. Table 3 shows responses to these questions based on status (retiree or worker) and by the form of distribution (annuity or present value sum) selected

\footnotetext{
${ }^{4}$ Missing values from no response to the questions were not factored into subset totals.
} 
in 1997.5 Section One further asked respondents to self-evaluate the accuracy of their risk perceptions ten years after making the distribution decision. The self-evaluation period included a rising equity market (1997-early 1999), a declining equity market (late 1999-2002), historically very low rates of return on fixed income investments, and historically high costs for basic necessities such as gasoline and utilities. Table 4 shows responses to these self-evaluation questions by retiree and worker status.

Table 3: Risk Perceptions and Distribution Decisions (1997)

\begin{tabular}{|c|c|c|c|c|c|}
\hline & \multirow[b]{2}{*}{ Total (\%) } & \multicolumn{2}{|c|}{ RETIREES } & \multicolumn{2}{|c|}{ WORKERS } \\
\hline & & Present Value & Annuity & Present Value & Annuity \\
\hline \multicolumn{6}{|l|}{ Longevity Risk } \\
\hline High & $49.40 \%$ & $11.11 \%$ & $100.00 \%$ & $55.81 \%$ & $66.67 \%$ \\
\hline Medium & $20.80 \%$ & $44.44 \%$ & $0.00 \%$ & $13.95 \%$ & $33.33 \%$ \\
\hline Low & $29.90 \%$ & $44.44 \%$ & $0.00 \%$ & $30.23 \%$ & $0.00 \%$ \\
\hline Valid & $77(100 \%)$ & $18(100 \%)$ & $4(100 \%)$ & $43(100 \%)$ & $3(100 \%)$ \\
\hline \multicolumn{6}{|l|}{ Inflation Risk } \\
\hline High & $57.00 \%$ & $31.58 \%$ & $50.00 \%$ & $70.45 \%$ & $66.67 \%$ \\
\hline Medium & $26.60 \%$ & $47.37 \%$ & $50.00 \%$ & $20.45 \%$ & $0.00 \%$ \\
\hline Low & $16.50 \%$ & $21.05 \%$ & $0.00 \%$ & $9.09 \%$ & $33.33 \%$ \\
\hline Valid & $79(100 \%)$ & $19(100 \%)$ & $4(100 \%)$ & $44(100 \%)$ & $3(100 \%)$ \\
\hline \multicolumn{6}{|l|}{ Investment Risk } \\
\hline High & $21.30 \%$ & $10.53 \%$ & $0.00 \%$ & $31.82 \%$ & $33.33 \%$ \\
\hline Medium & $45.00 \%$ & $57.89 \%$ & $80.00 \%$ & $38.64 \%$ & $0.00 \%$ \\
\hline Low & $33.80 \%$ & $31.58 \%$ & $20.00 \%$ & $29.55 \%$ & $66.67 \%$ \\
\hline Valid & $80(100 \%)$ & $19(100 \%)$ & $5(100 \%)$ & $44(100 \%)$ & $3(100 \%)$ \\
\hline \multicolumn{6}{|l|}{ Medical Expense Risk } \\
\hline High & $78.30 \%$ & $60.00 \%$ & $83.33 \%$ & $86.21 \%$ & $66.67 \%$ \\
\hline Medium & $21.70 \%$ & $40.00 \%$ & $16.67 \%$ & $13.79 \%$ & $33.33 \%$ \\
\hline Low & $0.00 \%$ & $0.00 \%$ & $0.00 \%$ & $0.00 \%$ & $0.00 \%$ \\
\hline Valid & $60(100 \%)$ & $15(100 \%)$ & $6(100 \%)$ & $29(100 \%)$ & $3(100 \%)$ \\
\hline \multicolumn{6}{|l|}{$\begin{array}{l}\text { Long-Term Care Expense } \\
\text { Risk }\end{array}$} \\
\hline High & $67.40 \%$ & $63.64 \%$ & $100.00 \%$ & $60.00 \%$ & $100.00 \%$ \\
\hline Medium & $32.60 \%$ & $36.36 \%$ & $0.00 \%$ & $40.00 \%$ & $0.00 \%$ \\
\hline Low & $0.00 \%$ & $0.00 \%$ & $0.00 \%$ & $0.00 \%$ & $0.00 \%$ \\
\hline Valid & $43(100 \%)$ & $11(100 \%)$ & $5(100 \%)$ & $20(100 \%)$ & $1(100 \%)$ \\
\hline
\end{tabular}

\footnotetext{
${ }^{5}$ The researcher did not attempt to control for the potential problem of recall bias in Table 3 above and Table 5, infra.
} 
Table 4: Self-Evaluation of Risk Perceptions (2007)

\begin{tabular}{|c|c|c|c|c|c|c|c|c|c|c|}
\hline & \multicolumn{5}{|c|}{ RETIREES } & \multicolumn{5}{|c|}{ WORKERS } \\
\hline & $\begin{array}{l}\text { Too } \\
\text { Low }\end{array}$ & $\begin{array}{l}\text { About } \\
\text { Right }\end{array}$ & $\begin{array}{l}\text { Too } \\
\text { High }\end{array}$ & $\begin{array}{c}\text { Doesn't } \\
\text { Apply }\end{array}$ & $\begin{array}{c}\text { Total } \\
\text { Retirees } \\
\text { Responding }\end{array}$ & $\begin{array}{l}\text { Too } \\
\text { Low }\end{array}$ & $\begin{array}{l}\text { About } \\
\text { Right }\end{array}$ & $\begin{array}{l}\text { Too } \\
\text { High }\end{array}$ & $\begin{array}{c}\text { Doesn't } \\
\text { Apply }\end{array}$ & $\begin{array}{c}\text { Total } \\
\text { Workers } \\
\text { Responding }\end{array}$ \\
\hline $\begin{array}{l}\text { Longevity } \\
\text { Risk } \\
\text { Inflation }\end{array}$ & $16.67 \%$ & $62.50 \%$ & $0.00 \%$ & $20.83 \%$ & 24 & $28.85 \%$ & $46.15 \%$ & $3.85 \%$ & $21.15 \%$ & 52 \\
\hline $\begin{array}{l}\text { Risk } \\
\text { Investment }\end{array}$ & $45.83 \%$ & $45.83 \%$ & $0.00 \%$ & $8.33 \%$ & 24 & $26.92 \%$ & $46.15 \%$ & $11.54 \%$ & $15.38 \%$ & 52 \\
\hline $\begin{array}{l}\text { Risk } \\
\text { Medical }\end{array}$ & $29.17 \%$ & $41.67 \%$ & $20.83 \%$ & $8.33 \%$ & 24 & $30.77 \%$ & $44.23 \%$ & $13.46 \%$ & $11.54 \%$ & 52 \\
\hline $\begin{array}{l}\text { Expense } \\
\text { Risk } \\
\text { Long-Term } \\
\text { Care }\end{array}$ & $65.38 \%$ & $23.08 \%$ & $3.85 \%$ & $7.69 \%$ & 26 & $40.38 \%$ & $23.08 \%$ & $13.46 \%$ & $23.08 \%$ & 52 \\
\hline $\begin{array}{l}\text { Expense } \\
\text { Risk }\end{array}$ & $36.00 \%$ & $20.00 \%$ & $4.00 \%$ & $40.00 \%$ & 25 & $21.15 \%$ & $13.46 \%$ & $1.92 \%$ & $63.46 \%$ & 52 \\
\hline
\end{tabular}

Table 3 shows that, not surprisingly, 100\% of retirees who selected an annuity recalled that they perceived longevity risk as high in 1997, whereas almost $90 \%$ of retirees who selected the present value sum recalled their perception of longevity risk in 1997 as medium to low. Among workers who selected a present value sum, 70.45\% recalled perceiving inflation risk as high as compared with $31.82 \%$ who recalled perceiving investment risk as high in 1997.

Although more than $75 \%$ of retirees and workers recalled perceiving medical care expense risk as high in 1997, the largest percentage of respondents in both status groups self-evaluated their 1997 perception of medical care expense risk as too low. Among retirees, inflation risk had the second largest percentage of respondents self-evaluating their 1997 risk perception as too low. For workers, the second largest percentage of respondents self-evaluated their perception of investment risk as too low.

Section Two of the survey asked respondents to recall their motivations for the distribution decision in 1997 and identify the motivating factors that played a "major" role in the decision. Table 5 shows the responses according to the respondent's status (retiree or worker) in 1997. 
Table 5: Major Factors Motivating Distribution Decision

\begin{tabular}{|c|c|c|c|}
\hline & RETIREES & WORKERS & Significance $^{6}$ \\
\hline Tax Penalty & $58.30 \%$ & $52.00 \%$ & 0.793 \\
\hline Social Security Annuity & $52.00 \%$ & $26.90 \%$ & 0.057 \\
\hline Personal Savings and Investments & $42.30 \%$ & $15.10 \%$ & 0.017 \\
\hline Spousal Annuity & $24.00 \%$ & $21.20 \%$ & 1.000 \\
\hline Immediate Purchase & $3.80 \%$ & $9.60 \%$ & $\mathrm{n} / \mathrm{a}$ \\
\hline Inheritance (Bequest) & $38.50 \%$ & $23.10 \%$ & 0.247 \\
\hline Debt Reduction & $0.00 \%$ & $11.54 \%$ & $\mathrm{n} / \mathrm{a}$ \\
\hline Investment Control & $65.40 \%$ & $44.20 \%$ & 0.128 \\
\hline Investment Passivity & $20.00 \%$ & $11.80 \%$ & 0.541 \\
\hline Personal Income Security & $24.00 \%$ & $23.10 \%$ & 1.000 \\
\hline Spousal Income Security & $20.80 \%$ & $21.60 \%$ & 1.000 \\
\hline
\end{tabular}

More than $60 \%$ of retirees recalled that the desire to control the investment of their retirement benefits was a major factor in the distribution decision. For workers, this percentage was less $(44.20 \%)$, but the difference between status groups was not statistically significant. For both status groups, more than half of the respondents recalled that the tax penalty associated with a lump sum distribution was a major factor in the distribution decision. These two motivations are consistent with the relatively high percentage of total survey respondents $(62.03 \%)$ who chose a nontaxable direct rollover distribution. For retirees, the third largest percentage of respondents recalled the lifetime annuity payments for Social Security benefits as a major factor in the distribution decision. The annuity provided by Social Security and other personal savings and investments were both significantly more important as major factors for retirees than for workers. The bequest motive as a major factor in the distribution decision was not significantly more important for retirees than for workers. A desire for personal or spousal income security was a major factor in the distribution decision for less than onefourth of respondents among retirees and among workers. A desire to use retirement benefits to make an immediate purchase in the near future was identified as a major factor by less than $5 \%$ of retirees and less than $10 \%$ of workers.

\footnotetext{
${ }^{6}$ Chi-square test results comparing retirees and workers. Factors in bold are significant at the 0.05 level.
} 
Section Three of the survey asked respondents questions about how their retirement benefits were invested and whether their retirement benefits had been used to pay medical care or long-term care expenses during the ten-year period following the distribution decision (1997-2007). Section Three further asked respondents to identify their level of satisfaction with the distribution decision made in 1997. Responses are shown in Tables 6, 7 and 8.

Table 6: Investment Experience

\begin{tabular}{|l|c|c|c|}
\cline { 2 - 4 } \multicolumn{1}{c|}{} & \multicolumn{2}{c|}{} & \multicolumn{2}{c|}{ Respondents } \\
\cline { 2 - 4 } \multicolumn{1}{c|}{} & $\begin{array}{c}\text { Total } \\
\text { Investing by } \\
\text { Type }\end{array}$ & RETIREES & WORKERS \\
\hline $\begin{array}{l}\text { Individual } \\
\text { Stocks }\end{array}$ & 22 & $25.00 \%$ & $25.53 \%$ \\
\hline Bonds & 17 & $27.50 \%$ & $12.77 \%$ \\
\hline Mutual Funds & 36 & $32.50 \%$ & $48.94 \%$ \\
\hline Real Estate & 4 & $7.50 \%$ & $2.13 \%$ \\
\hline Other & 6 & $7.50 \%$ & $6.38 \%$ \\
\hline Did not invest & 2 & $0.00 \%$ & $4.26 \%$ \\
\hline
\end{tabular}

Table 6 shows that the largest percentage of respondents in both status groups invested their retirement benefits in mutual funds. Among retirees, the second highest percentage invested in bonds, whereas for workers the second highest percentage invested in the stock of individual companies.

Table 7: Benefit Consumption For Medical And Long-Term Care Expenses

\begin{tabular}{|l|c|c|c|c|}
\cline { 2 - 5 } \multicolumn{1}{c|}{} & \multicolumn{2}{c|}{ RETIREES } & \multicolumn{2}{c|}{ WORKERS } \\
\cline { 2 - 5 } \multicolumn{1}{c|}{} & Medical & Long-Term Care & Medical & Long-Term Care \\
\hline Did not spend benefits & $64.00 \%$ & $75.00 \%$ & $78.43 \%$ & $92.16 \%$ \\
\hline Did spend benefits & $36.00 \%$ & $25.00 \%$ & $21.57 \%$ & $7.84 \%$ \\
\hline
\end{tabular}

Table 7 shows that more than one-third of retirees and more than one-fifth of workers had used their retirement benefits to pay medical care expenses for themselves, a spouse, a dependent child, or an elderly parent at some time during the ten-year period following the 1997 distribution decision. In addition, one-fourth of retirees had used their retirement benefits to pay for long-term care expenses for themselves, a spouse, a dependent child, or an elderly parent. 
Table 8: Level of Satisfaction With Distribution Decision

\begin{tabular}{|c|c|c|c|}
\hline & \multirow[b]{3}{*}{ Total } & \multirow{2}{*}{\multicolumn{2}{|c|}{ Respondents }} \\
\hline & & & \\
\hline & & RETIREES & WORKERS \\
\hline Satisfied / Very Satisfied & $81.69 \%$ & $91.67 \%$ & $76.60 \%$ \\
\hline Valid & 58 & 22 & 36 \\
\hline Neutral / No Opinion & $9.86 \%$ & $8.33 \%$ & $10.64 \%$ \\
\hline Valid & 7 & 2 & 5 \\
\hline Dissatisfied / Very Dissatisfied & $8.45 \%$ & $0.00 \%$ & $12.77 \%$ \\
\hline Valid & 6 & 0 & 6 \\
\hline
\end{tabular}

Table 8 shows that more than $90 \%$ of retirees and more than $75 \%$ of workers were either satisfied or very satisfied with the distribution decision they made in 1997. No retirees indicated that they were dissatisfied with their 1997distribution decision.

Section Four of the survey was limited to respondents who were classified as retirees (age 62 or older at the time of the distribution decision in 1997). Section Four asked retirees a series of questions concerning the adequacy of retirement household income and current and anticipated future expenditures for daily living expenses, medical care, long-term care and prescription drugs. Slightly more than $90 \%$ of retirees agreed that their household income during the past twelve months had been enough to pay for their daily living expenses, including insurance premiums for medical care (including Medicare coverage), long-term care, and prescription drug insurance coverage. However, only $65.2 \%$ of retirees agreed that their household income would be enough to pay for these expenses in the future. More than $50 \%$ of retirees agreed that their household income in the future would be enough to pay for medical care expenses that were not covered by insurance, and more than $65 \%$ of retirees agreed that their household income in the future would be enough to pay for prescription drugs not covered by insurance. In contrast, only $17.4 \%$ of retirees agreed that their household income in the future would be enough to pay for long-term care expenses not otherwise covered by insurance.

Section Five of the survey was designed to assess the respondent's financial 
literacy and efforts at retirement planning by using the module questions on planning and financial literacy that were administered as part of the 2004 Health and Retirement Study (Lusardi and Mitchell 2006a). Tables 9 and 10 show the respondents' correct responses to the three financial literacy questions and the joint probabilities of correct answers on these questions.

\section{Table 9: Distribution of Responses to Financial Literacy Questions ${ }^{7}$}

\begin{tabular}{|l|c|c|c|}
\cline { 2 - 4 } \multicolumn{1}{c|}{} & \multicolumn{3}{c|}{ Responses (N = 82) } \\
\cline { 2 - 4 } \multicolumn{1}{c|}{} & Correct & Incorrect & No Response / Refused \\
\hline Compound Interest & $85.4 \%$ & $8.5 \%$ & $6.10 \%$ \\
\hline Inflation & $87.8 \%$ & $4.9 \%$ & $7.30 \%$ \\
\hline Stock Risk & $79.3 \%$ & $12.2 \%$ & $8.50 \%$ \\
\hline
\end{tabular}

Table 10: Joint Probabilities of Correctly Answering Financial Literacy Questions

\begin{tabular}{|c|c|c|c|c|}
\cline { 2 - 5 } \multicolumn{1}{c|}{} & All 3 responses correct & $\begin{array}{c}\text { Only 2 responses } \\
\text { correct }\end{array}$ & $\begin{array}{c}\text { Only 1 response } \\
\text { correct }\end{array}$ & No responses correct \\
\hline & & & & $0.0 \%$ \\
\hline
\end{tabular}

Tables 9 and 10 show that a much higher percentage of survey respondents (74\%) correctly answered all three of the three financial literacy questions as compared with the survey respondents to the 2004 Health and Retirement Study module. For the 2004 Health and Retirement Study module, only $67.1 \%, 75.2 \%$, and $52.3 \%$ of respondents correctly answered the compound interest, inflation, and stock risk questions, and only $34.3 \%$ correctly answered all three financial literacy questions (Lusardi and Mitchell 2006a).

Section Six of the survey asked respondents to provide personal demographic information and offered the opportunity to make additional open-ended comments. The demographic data produced by Section Six are contained in Table 2 above. The survey

\footnotetext{
${ }^{7}$ Unlike the 2004 HRS module, the survey instrument did not include pre-defined answers to capture and distinguish between "Don't Know" or "Refuse" responses. Non-responses by way of a blank response to the survey questions were recorded as missing values and tabulated as the single variable "No Response / Refused."
} 
data on demographic data, financial literacy, and efforts at retirement planning will be analyzed separately in a future paper.

\section{Discussion and Tentative Conclusions}

In reviewing the preliminary data results, three general themes emerge. First, in making distribution decisions, plan participants may need more and better information to assess the financial risks presented by uninsured medical care expenses in retirement. Although medical care expense risk was perceived as high by most retirees at the time of the distribution decision, subsequent self-evaluation indicated that many retirees had underestimated the financial risk associated with uninsured medical care expenses. In fact, more than one-third of retirees reported actually spending a portion of their retirement benefits on medical care expenses not covered by insurance.

The second theme that emerges from the preliminary data is the important role that federal tax and social welfare policies may play in an individual's distribution decision. Survey respondents indicated that federal tax policy penalizing lump sum distributions and the lifetime annuity payments provided by Social Security were the most prevalent major factors considered in making the distribution decision. Further individual-level research on the distribution decision-making process could prove valuable to policymakers in assessing the potential impact of proposals to amend federal tax and social welfare policies.

The third theme is cautious optimism that, in the future, financially literate individuals as retirees will be able to successfully manage a present value sum distribution during retirement. The survey respondents evidenced a relatively high level of financial literacy. Slightly more than ninety percent (90.9\%) of retirees who responded to the survey indicated that, in the tenth year following their distribution decision, they had a sufficient household income to pay for their daily living expenses, including the costs of premiums for health care-related insurance coverage. More than $90 \%(91.67 \%)$ of retirees indicated that they were satisfied with their distribution decision, and none of the retirees who responded to the survey were dissatisfied with their distribution decision. 
Perhaps the most important conclusion to be drawn from the survey is that, although there are methodological challenges to be overcome, it is possible to collect individual-level data on the perceptions and decision-making processes used by retirement plan participants in making distribution decisions. Such individual-level data is a potentially valuable resource for state and local government officials as they evaluate public pension systems in light of future fiscal challenges. Individual-level data also is likely to provide valuable insights as researchers seek to understand the annuity puzzle. In particular, individual-level data can be used to create financial products that combine annuity features with other features, such as an ability to have some measure of control over investments, that will appeal to the motivations of workers who are entering the retirement phase. Finally, individual-level data can be used to improve the content of both public financial literacy programs and private efforts by employers to provide workers with retirement financial education.

\section{Acknowledgments}

The researcher gratefully acknowledges the technical assistance and support provided by the staff of the Bureau of Sociological Research at the University of Nebraska-Lincoln and its director, Dr. Julia McQuillan. The researcher also acknowledges the gracious cooperation of the Nebraska Public Employees Retirement System, its former director, Anna J. Sullivan, and its current director, Phyllis Chambers, without whose support this project would not have been possible. 


\section{References}

Armstrong, J. Scott, and Terry S. Overton. 1977. "Estimating Nonresponse Bias in Mail Surveys." Journal of Marketing Research 14(3): 396-402.

Brown, Jeffrey R., Olivia S. Mitchell, James M. Poterba, and Mark J. Warshawsky. 2001. The Role of Annuity Markets in Financing Retirement. Cambridge, Mass.: MIT Press, 2001.

Butrica, Barbara A., and Gordon B.T. Mermin. 2006. "Annuitized Wealth and Consumption at Older Ages." Washington, D.C.: The Urban Institute.

Coile, Courtney, and Kevin Milligan. 2006. "How Household Portfolios Evolve After Retirement: The Effect of Aging and Health Shocks."

Copeland, Craig. 2007. "How Are New Retirees Doing Financially in Retirement?" Issue Brief No. 302. Washington, D.C.: Employee Benefit Research Institute.

Davidoff, Thomas, Jeffrey R. Brown, and Peter Diamond. 2005. "Annuities and Individual Welfare." Working Paper 03-15. Cambridge, Mass.: Massachusetts Institute of Technology.

Dillman, D.A. 2007. Mail and Internet Surveys: The Tailored Design Method. Hoboken, NJ: Wiley.

Dus, Ivica, Raimond Maurer, and Olivia S. Mitchell. 2004. "Betting on Death and Capital Markets in Retirement: A Shortfall Risk Analysis of Life Annuities Versus Phased Withdrawal Plans." Working Paper 2004-1. Philadelphia, Penn.: Pension Research Council.

Dushi, Irena, and Anthony Webb. 2004. “Annuitization: Keeping Your Options Open.” Ann Arbor, Mich.: University of Michigan Center for Retirement Research.

Horneff, Wolfram J., Raimond Maurer, Olivia S. Mitchell, and Ivica Dus. 2006. "Optimizing the Retirement Portfolio: Asset Allocation, Annuitization, and Risk Aversion.” Working Paper 2006-10. Philadelphia, Penn.: Pension Research Council.

Hu, Wei-Yin, and Jason S. Scott. 2007. "Behavioral Obstacles to the Annuity Market." Working Paper 2007-10. Philadelphia, Penn.: Pension Research Council.

Hurd, Michael D., and Susann Rohwedder. 2006. "Some Answers to the Retirement Consumption Puzzle." Working Paper 12057. Cambridge, Mass.: National Bureau of Economic Research. 
Lusardi, Annamaria, and Olivia S. Mitchell. 2006a. "Financial Literacy and Planning: Implications for Retirement Well-Being."

Lusardi, Annamaria, and Olivia s. Mitchell. 2006b. "Baby Boomer Retirement Security: The Role of Planning, Financial Literacy, and Housing Wealth." Working Paper 200702. Philadelphia, Penn.: Pension Research Council.

Knäuper, Bärbell, Robert F. Belli, Danniel H. Hill and A. Regula Herzog. 1997. "Question Difficulty and Respondents' Cognitive Ability: The Effect on Data Quality." Journal of Official Statistics 13(2): 181-199.

Moore, Danna L., and John Tarnai. 2002. Evaluating Nonresponse Error in Mail Surveys. In Survey Nonresponse, ed. Don A. Dillman, John L. Eltinge, and Roderick J.A. Little, 197-211. New York: John Wiley \& Sons Inc.

Munnell, Alicia, and Annika Sundén. 2004. Coming Up Short: The Challenge of 401(k) Plans. Washington, D.C.: The Brookings Institution.

Rohwedder, Susann. 2006. "Self-Assessed Retirement Outcomes: Determinants and Pathways." Working Paper 2006-141. Ann Arbor, Mich.: University of Michigan Retirement Research Center.

Rohwedder, Susann, and Arthur Van Soest. 2006. "The Impact of Misperceptions about Social Security on Saving and Well-being." Working Paper 2006-118. Ann Arbor, Mich.: University of Michigan Retirement Research Center.

Scott, Jason S., John G. Watson, and Wei-Yin Hu. 2007. "Efficient Annuitization: Optimal Strategies for Hedging Mortality Risk.” Working Paper 2007-09. Philadelphia, Penn.: Pension Research Council.

Van Soest, Arthur, and Arie Kapetyn. 2006. "Savings, Portfolio Choice, and Retirement Expectations." Working Paper 2006-119. Ann Arbor, Mich.: University of Michigan Retirement Research Center. 


\title{
RECENT WORKING PAPERS FROM THE
}

\section{CENTER FOR RETIREMENT RESEARCH AT BOSTON COLLEGE}

\author{
A Micro-Level Analysis of Recent Increases in Labor Participation Among Older \\ Workers
}

Kevin E. Cahill, Michael D. Giandrea, and Joseph F. Quinn, February 2008

The Trajectory of Wealth in Retirement

David A. Love, Michael G. Palumbo, and Paul A. Smith, February 2008

The Rising Age at Retirement in Industrial Countries

Gary Burtless, February 2008

The Implications of Career Lengths for Social Security

Melissa M. Favreault and C. Eugene Steuerle, February 2008

Do Out-of-Pocket Health Care Costs Delay Retirement?

Richard W. Johnson, Rudolph G. Penner, and Desmond Toohey, February 2008

How the Income and Tax Treatment of Saving and Social Security Benefits May Affect Boomers' Retirement Incomes

Barbara A. Butrica, Karen E. Smith, and Eric J. Toder, February 2008

Saving and Wealth Accumulation in the PSID, 1984-2005

Barry P. Bosworth and Sarah Anders, February 2008

Older Women's Income and Wealth Packages in Cross-National Perspective

Timothy M. Smeeding, Janet C. Gornick, Eva Sierminska, and Maurice Leach, Feb. 2008

How Many Struggle to Get By in Retirement?

Barbara A. Butrica, Daniel Murphy, and Sheila R. Zedlewski, January 2008

The Impact of Late-Career Health and Employment Shocks on Social Security and Other Wealth

Richard W. Johnson, Gordon B.T. Mermin, and Dan Murphy, December 2007

The Effect of Economic Conditions on the Employment of Workers Nearing Retirement Age

Till von Wachter, December 2007 